This is the author's final, peer-reviewed manuscript as accepted for publication. The publisher-formatted version may be available through the publisher's web site or your institution's library.

\title{
Impact of commercial natural gas production on geochemistry and microbiology in a shale-gas reservoir
}

Matthew F. Kirk, Anna M. Martini, Daniel O. Breecker, Daniel R. Colman, Cristina

Takacs-Vesbach, Steven T. Petsch

\section{How to cite this manuscript}

If you make reference to this version of the manuscript, use the following information:

Kirk, M. F., Martini, A. M., Breecker, D. O., Colman, D. R., Takacs-Vesback, C., \& Petsch, S. T. (2012). Impact of commercial natural gas production on geochemistry and microbiology in a shale-gas reservoir. Retrieved from http://krex.ksu.edu

\section{Published Version Information}

Citation: Kirk, M. F., Martini, A. M., Breecker, D. O., Colman, D. R., Takacs-Vesback, C., \& Petsch, S. T. (2012). Impact of commercial natural gas production on geochemistry and microbiology in a shale-gas reservoir. Chemical Geology, 332-333, 15-25.

Copyright: () 2012 Elsevier B.V.

Digital Object Identifier (DOI): doi:10.1016/j.chemgeo.2012.08.032

Publisher's Link: http://www.sciencedirect.com/science/article/pii/S0009254112003919

This item was retrieved from the K-State Research Exchange (K-REx), the institutional repository of Kansas State University. K-REx is available at http://krex.ksu.edu 
3

4 5

6

11

$12{ }^{5}$ Current address: Department of Geology, Kansas State University, Manhattan, KS 66506-3201

13 *Corresponding author: matthew.f.kirk@gmail.com, office +1 785-532-6724, fax +1 785-532-

14

15

16

17

18

\section{Impact of commercial natural gas production on geochemistry and} microbiology in a shale-gas reservoir

Matthew F. Kirk ${ }^{1,5, *}$, Anna M. Martini ${ }^{1}$, Daniel O. Breecker ${ }^{2}$, Daniel R. Colman ${ }^{3}$, Cristina Takacs-Vesbach ${ }^{3}$, Steven T. Petsch ${ }^{4}$

${ }^{1}$ Department of Geology, Amherst College, Amherst, MA 01002, USA ${ }^{2}$ Department of Geological Sciences, University of Texas, Austin, TX 78712, USA 1 4 5159 15

Resubmitted to

Chemical Geology

August 16, 2012 
Abstract [310 words]

We consider the effect that commercial gas production has had on microbiology and

21 water and gas geochemistry in the northern producing trend of the Antrim Shale, an

22 unconventional gas reservoir in the Michigan Basin, USA. We analyzed gas, water, and

microbial biomass samples collected from seven wells in 2009 and compared our findings to the

24 result of analyses performed as early as 1991 on samples collected from the same wells. We also examined production records associated with six wells. Water production has decreased sharply over time and is currently at 0.2 to $14.6 \%$ of peak levels. While this has happened, the chemical

27 and isotopic composition of gas and water produced from the wells has shifted. The proportion of $\mathrm{CO}_{2}$ has increased by as much as 15 mole $\%$ while $\mathrm{CH}_{4}$ content has correspondingly

29 decreased. Isotopically, the $\delta^{13} \mathrm{C}$ and $\delta \mathrm{D}$ values of $\mathrm{CH}_{4}$ decreased for most wells by averages of $1.3 \%$ and $9 \%$, respectively, while $\delta^{13} \mathrm{C}$ values of $\mathrm{CO}_{2}$ increased for most wells by an average of 1.7\%. Alkalinity in the water from each well decreased by $10 \mathrm{mM}$ on average and $\mathrm{SO}_{4}{ }^{2-}$ content increased from below $50 \mu \mathrm{M}$ to over $200 \mu \mathrm{M}$ on average in water from each well with initial values. Microorganisms most closely related to $\mathrm{CO}_{2}$-reducing methanogens were the most 34 abundant group in archaeal clone libraries and $\mathrm{SO}_{4}{ }^{2-}$ reducers were the most abundant group in 35 bacterial libraries. In contrast, no $\mathrm{SO}_{4}{ }^{2-}$ reducers were identified in a nucleic acid-based analysis 36 of a sample collected in 2002 from one of the wells we sampled. Our results show that 37 commercial gas production has not only caused chemical and isotopic changes in water and gas 38 in the Antrim Shale but also an increase in the abundance of $\mathrm{SO}_{4}{ }^{2-}$-reducing microorganisms, a change that can ultimately have a negative impact on biogenic $\mathrm{CH}_{4}$ formation. Processes that can explain these changes include ongoing biogeochemical reactions, groundwater flow, gas

41 desorption, and open-system degassing. 
43 Keywords: sulfate reduction, methanogenesis, Antrim Formation, Michigan Basin, unconventional natural gas reservoir, black shale

\section{Introduction}

Unconventional natural gas reservoirs such as fractured organic-rich shale are becoming increasingly important energy resources. Natural gas provides a major source of energy for the U.S., accounting for more than $20 \%$ of the energy supply (NETL, 2009). The rate of gas consumption, however, increasingly exceeds the rate of domestic production. Greater production

51 from fractured organic-rich shale can help make up some of this imbalance (NETL, 2009).

52 Moreover, although carbon dioxide $\left(\mathrm{CO}_{2}\right)$ is emitted during gas combustion, natural gas is the 53 cleanest fossil fuel. Compared to coal, for example, natural gas combustion emits about half as

54 much $\mathrm{CO}_{2}$ per joule of energy produced, as well as far lower $\mathrm{NO}_{\mathrm{x}}, \mathrm{SO}_{\mathrm{x}}$, heavy metals and 55 particulate matter. Producing a greater percentage of our energy from natural gas at the expense 56 of oil and coal, therefore, would be environmentally advantageous (White et al., 2003).

57 In many unconventional natural gas reservoirs, a significant portion of the gas formed 58 biologically as microbial communities degraded sedimentary organic matter (e.g., Bates et al., 59 2011; Flores et al., 2008; Formolo et al., 2008; Martini et al., 1996; McIntosh et al., 2008; McIntosh et al., 2002; Schlegel et al., 2011; Scott et al., 1994; Strąpoć et al., 2008; Su et al.,

61 2005; Waldron et al., 2007; Warwick et al., 2008). Biological formation of methane $\left(\mathrm{CH}_{4}\right)$, the 62 primary component of natural gas, requires a consortium of microorganisms. Fermentative and 63 syntrophic Bacteria degrade complex organic matter and ultimately produce substrates that can 64 be used by methanogenic Archaea as energy sources (Conrad, 1999). Methanogens primarily use 
acetate $\left(\mathrm{CH}_{3} \mathrm{COO}^{-}\right)$or dihydrogen $\left(\mathrm{H}_{2}\right)$ as their substrate (Conrad, 1999), producing $\mathrm{CH}_{4}$ by acetate fermentation or $\mathrm{CO}_{2}$ reduction, respectively:

$$
\begin{aligned}
& \mathrm{CH}_{3} \mathrm{COO}^{-}+\mathrm{H}^{+} \rightarrow \mathrm{CH}_{4}+\mathrm{CO}_{2} \\
& \mathrm{CO}_{2}+4 \mathrm{H}_{2} \rightarrow 2 \mathrm{H}_{2} \mathrm{O}+\mathrm{CH}_{4}
\end{aligned}
$$

How these microbial processes are affected by commercial production of natural gas is unclear. Gas is stored in shale reservoirs primarily by adsorption to the solid matrix (Scott et al., 1994). To harvest the gas, water is pumped out of the formation, which lowers pressure adjacent to the borehole and allows the gas to desorb (Martini et al., 2003). We hypothesize this process could impact microbial activity by drawing water into the shale that has a different composition than the water present before development. Such changes may affect subsurface microbes because, while microbes affect the composition of their environment by driving reactions forward, the environment also influences microbial activity by providing electron donors and acceptors and other nutrients (Jin and Bethke, 2007). Potential shifts in water composition driven by pumping, therefore, may impact microbial activity and ultimately $\mathrm{CH}_{4}$ formation.

This study examines how commercial production of natural gas has affected geochemistry and microbiology in the Devonian Antrim Shale along the northern margin of the Michigan Basin. Waldron et al. (2007) found evidence that commercial gas production there is causing $\mathrm{SO}_{4}{ }^{2-}$ concentration to increase, a change that could negatively impact methanogenesis. This finding warrants further study to fully evaluate how geochemistry has changed and identify consequences for microbial activity, information that has implications for the sustainability of gas production in unconventional gas reservoirs. The Antrim Shale provides an ideal field site to examine this question; the formation was one of the earliest shale-gas reservoirs to be developed (Curtis, 2002) and conditions soon after widespread development are well documented (see data 
88 available in Martini et al., 1998). Furthermore, most of the gas produced commercially along the

89 northern edge of the basin (i.e., the northern producing trend) is biogenic (Martini et al., 1996;

90 Martini et al., 1998). Our analysis is constrained by data gathered soon after widespread

91 development of the northern producing trend in the early 1990s, data collected from one well in

92 2002, and data we collected in 2009.

93

94 2. Materials and methods

95 2.1. Commercial gas wells

96 We selected seven wells along the northern producing trend that had originally been

97 sampled in the early 1990s and re-sampled them during January, 2009. One well, ID\# 150, was

98 also sampled again in 2002. Data collected from the initial set of samples were published in

99 Martini et al. (1996; 1998) and Walter et al. (1996). Data from 2002 samples were published in

100 Martini et al. (2005) and Formolo et al. (2008). Site numbers used in this study are consistent

101 with those used in Martini et al. (1998), with the exception of two wells, B and M, which were

102 not included in that publication.

103 Information about each well is summarized in the Supplemental Content (Table SC1). An

104 annotated map showing the location of each well accompanies the online version of this article.

105 Additional maps showing regional variation in pore water composition are available in Martini et

106 al. (1998) and Waldron et al. (2007).

107

108

\subsection{Sample collection}

Temperature and $\mathrm{pH}$ measurements were made in the field for a subset of wells. Gas

110 samples were collected for compositional and isotopic analyses in Isotubes ${ }^{\circledR}$ (Isotech 
111 Laboratories, Inc.). Water samples were collected for chemical and isotopic analyses and

112 microbial analyses in acid-washed and sterile bottles, respectively. Chemical and isotopic

113 samples were filtered using $0.22 \mu \mathrm{m}$ nylon syringe filters. Cation samples were preserved at $\mathrm{pH}$

$114<2$ with trace-metal grade $\mathrm{HNO}_{3}$. Microbial biomass samples were collected by filtering water

115 through sterile $25 \mathrm{~mm} 0.22 \mu \mathrm{m}$ mixed cellulose-ester filter membranes. The samples were stored

116 in sterile $2 \mathrm{~mL}$ microcentrifuge tubes and preserved with $0.2 \mathrm{~mL}$ of sucrose lysis buffer

117 (Giovannoni et al., 1990). All sample filtration and preservation was performed within 12 hours

118 of sample collection rather than immediately in the field due to adverse weather conditions.

119 Samples were stored on ice in the field. In the lab, water samples were stored at $4^{\circ} \mathrm{C}$ and

120 microbial samples at $-20^{\circ} \mathrm{C}$.

121

122 2.3. Microbial analysis

123 Microbial biomass samples collected from wells 22, 147, and 150 were selected for

124 nucleic acid-based analysis. These wells were selected because they produce water with high,

125 intermediate, and low salinity. Previous research has shown that salinity is an important

126 constraint on microbial community composition in the northern producing trend (Waldron et al.,

127 2007). These wells, therefore, allow us to examine microbial communities across the range of

128 geochemical conditions present. Microbial biomass was also previously sampled from well 150

129 in 2002 and analyzed using methods similar to those we employed, which are described in

130 Formolo et al. (2008).

131

DNA was extracted from the filters using a MoBio ultra-clean soil DNA kit. The

132 alternative protocol described by the manufacturer was used to limit DNA shearing during the

133 extraction. 16S rRNA genes were amplified from the environmental DNA using universal 
134 135

primers 8F (5'-AGA GTT TGA TCM TGG CTC AG-3') and 1492R (5'-GGT TAC CTT GTT ACG ACT T-3') and archaeal primers 109F (5'-ACK GCT CAG TAA CAC GT-3') and 915R (5'-GTG CTC CCC CGC CAA TTC CT-3') (Grosskopf et al., 1998). PCR products were purified using a Wizard DNA gel purification kit and ligated into a TOPO TA vector. Cloning and sequencing was performed at the Washington University Genome Center. For each sample/primer pair, partial sequences were collected from 96 clones. Low quality sequence reads were excluded from subsequent analyses, leaving 213 bacterial sequences and 239 archaeal sequences, which all exceeded $300 \mathrm{bp}$ in length.

Sequences were aligned using the Greengenes NAST aligner (DeSantis et al., 2006a) and checked for chimeras using Bellerophon (DeSantis et al., 2006b). Operational taxonomic units (OTUs) were defined at $\geq 97 \%$ sequence identity using mothur (Schloss et al., 2009). Mothur was also used to identify representative sequences for each OTU and calculate rarefaction curves and Chao1 values for each clone library, which provide a measure of richness defined at the OTU level (Hughes et al., 2001). To evaluate which bacterial and achaeal groups were present in the samples, the taxonomy of representative sequences for each OTU was assessed using a naïve Bayesian rRNA classifier and an 80\% confidence threshold (Wang et al., 2007). We also employed this same procedure to classify sequences obtained from well 150 in 2002. Sequences obtained from well 150 samples collected in 2002 were deposited in the GenBank database under accession numbers EF117331-EF117417 and EF117512-EF117553. Sequences obtained from the samples collected in 2009 were deposited under accession numbers JX472462-JX472913.

2.4. Chemical and isotopic analysis 
Alkalinity was determined using Gran alkalinity titrations. $\mathrm{Cl}^{-}$and $\mathrm{SO}_{4}{ }^{2-}$ concentrations were measured at a precision of $2 \%$ using a Dionex AS50 ion chromatograph equipped with a CD20 conductivity detector, an ASRS 300 suppressor, and an IonPac AS14 column and AG14 guard column. $\mathrm{Cl}^{-}$was measured directly from diluted samples and $\mathrm{SO}_{4}{ }^{2-}$ was measured in samples that were treated with Dionex OnGuard II Ag cartridges to remove $\mathrm{Cl}^{-}$. $\mathrm{Na}^{+}, \mathrm{Ca}^{2+}, \mathrm{Mg}^{2+}$, and $\mathrm{Sr}^{2+}$ were measured at $3 \%$ precision and $\mathrm{K}^{+}$at $5 \%$ precision using a Leeman Labs ICP-AES. A suite of trace elements in each sample was measured using an Agilent 7500ce ICPMS. The instrument operated in reaction gas mode for select elements to eliminate mass interference. Samples and standards were acidified with Optima high-purity nitric acid to $3 \%$ by volume prior to analysis. Results were adjusted based upon recovery of a multi-element internal standard (SPEX CertiPrep).

Gas compositional and isotopic analyses and water isotopic analyses were performed at Isotech Laboratories, Inc. Gas composition was measured using gas chromatography. Hydrogen isotopic compositions of $\mathrm{CH}_{4}$ and water were measured using dual-inlet isotope ratio mass spectrometry (DI-IRMS) at 2\%o precision. Oxygen isotopic compositions of water and carbon isotopic compositions of $\mathrm{CH}_{4}, \mathrm{CO}_{2}$, dissolved inorganic carbon (DIC), and ethane were analyzed with DI-IRMS at $0.1 \%$ precision, with the exception of ethane sampled from wells 147,150 , and

M. In those samples, ethane carbon isotope compositions were measured using gas chromatography combustion isotope ratio mass spectrometry (GC-C-IRMS) at a precision of 0.3\%o. Water samples were prepared for isotopic analysis using the Indiana zinc method for hydrogen, $\mathrm{CO}_{2}$ equilibration for oxygen, and acid digestion for DIC. All isotopic compositions are reported in standard $\delta$ notation. Carbon isotopic compositions are reported relative to Vienna Pee Dee Belemnite (VPDB) and hydrogen and oxygen isotope compositions are reported relative 
180

181 185 statistical analysis of each parameter.

186

187

\subsection{Field station records} associated with each field station.

to Vienna Standard Mean Ocean Water (VSMOW). The precision of $\mathrm{CH}_{4}$ and water isotope values reported by Martini et al. $(1996 ; 1998)$, are identical to the errors in our analysis.

For this study, we did not consider differences between values we measured and the initial values to be important unless they differ by more than the potential analytical error of the initial and recent value combined. The limited amount of data available precluded a rigorous

To evaluate gas and water production over time at the field site, we obtained field station records from the Michigan Public Services commission for six of the wells we sampled. The records start when the field stations first came online and extend through 2007. A complete record was not available for the well field containing well 73.

Water and gas produced from multiple wells are delivered to each field station. The field stations in our dataset were fed by 22 wells on average. Withdrawals from the individual wells sampled for this study were estimated by dividing the total monthly gas and water production by the number of online wells in each field. It should be noted, however, that production levels can vary significantly among the wells in an individual field and our data do not constrain this variation. We could not evaluate, therefore, the extent to which the values we calculated accurately depict production levels for the wells we sampled. Nonetheless, the values we calculated still provide a useful measure of the average trends in water and gas production over time for the wells 


\section{Results}

\subsection{Microbial community composition}

Chaol values based on OTUs defined at $\geq 97 \%$ sequence identity were greater for

204 Bacteria than Archaea in all samples, indicating greater richness for Bacteria than Archaea at that similarity level (Fig. 1). Richness was greatest for Archaea in the 2009 sample with

206 intermediate salinity and greatest for Bacteria in the 2009 sample with the lowest salinity.

207 Strongly asymptotic rarefaction curves for each Archaea clone library (Supplementary Content

208 Fig. 1) indicate that the archaeal community was adequately sampled. Similarly, rarefaction 209 curves for bacterial clone libraries from well 22 and the 2002 sample from well 150 were also asymptotic. Curvilinear rarefaction curves for bacterial clone libraries from well 147 and the

2112009 sample from well 150, however, indicate that additional sequencing would be needed to

212 fully characterize the bacterial community in the water produced from those wells.

Taxonomic classification places all Archaea clones in the Euryarchaeota (Fig. 1A),

214 which contains the methanogens and extreme thermophiles and halophiles (Takacs-Vesbach et 215 al., 2001). Within this phylum, the majority of the archaeal clones obtained from 2009 samples 216 grouped within two orders of methanogenic microorganisms: Methanomicrobiales (59\%) and

217 Methanobacteriales (33\%). Methanobacteriales clones were most abundant in the lowest salinity 218 sample and Methanomicrobiales clones were most abundant in the highest salinity sample (Fig.

219 1A). Cultured members of these orders reduce $\mathrm{CO}_{2}$ typically with $\mathrm{H}_{2}$ as their electron donor, 220 although some can use formate or secondary alcohols (Bonin and Boone, 2006; Garcia et al., 221 2006). Methanosarcinales, the only order of methanogens that contains species capable of using 222 acetate, contributed little to the total Archaea clone library (3\%) obtained from 2009 samples. 
223 This result differed considerably from the results obtained from the 2002 sample from well 150 ,

224 in which most clones (69\%) grouped within Methanosarcinales (Fig. 1A).

225 Taxonomic classification of Bacteria shows that most of the clones obtained from 2009

226 samples are contributed from the phyla Proteobacteria (60\%), Firmicutes (22\%), and

227 Bacteroidetes (7\%), but that numerous other groups are also represented (Fig. 1B). Within the

228 Proteobacteria, most of the clones grouped within the orders Desulfovibrionales (48\%) and

229 Pseudomonadales (24\%) (Fig. 1C). Members of the Desulfovibrionales are primarily $\mathrm{SO}_{4}{ }^{2-}$

230 reducers (Garrity et al., 2005). Clones grouping within Desulfovibrionales were particularly

231 abundant in the sample collected from well 22 , in which they accounted for $78 \%$ of the total

232 bacterial clones. Pseudomonadales includes the genus Pseudomonas, which comprises a group

233 of species that are ubiquitous in soil and water ecosystems and capable of using a wide variety of

234 organic and inorganic compounds (Moore et al., 2006). Results obtained from the sample

235 collected in 2002 from well 150 contain similar groups of Bacteria as observed in 2009 samples.

236 Unlike the 2009 sample from well 150, however, no sequences grouping with Desulfovibrionales

237 were present in the 2002 clone library.

238

239 3.2. Chemical and isotopic composition of water

240 Field station records demonstrate that water production has decreased sharply over time

241 since the wells were developed. Water production peaked within the first five years of

242 production for all of the wells and both peak and cumulative levels were highest in the wells

243 furthest north (Fig. 2). Current levels of water production range from 0.2 to $14.6 \%$ of peak

244 levels. 
Although water production has declined, $\mathrm{pH}$, salinity, and bulk chemical composition has changed relatively little (Fig. 3; Supplemental Content Table SC2). As with the original samples,

247 the samples we analyzed were $\mathrm{Na}-\mathrm{Cl}$ type water with near-neutral to mildly acidic $\mathrm{pH}$ and 248 salinity generally increasing southward (i.e., basinward). Some aspects of the groundwater 249 composition were different, however. Alkalinity decreased in all of the wells by an amount 250 ranging from 3.1 to $22.3 \mathrm{mM} . \mathrm{Ca}^{2+}$ concentration decreased in five of seven wells by 1.5 to 8.9 $251 \mathrm{mM} . \mathrm{Mg}^{2+}$ content decreased in all of the wells by 2.1 to $33.7 \mathrm{mM}$. $\mathrm{SO}_{4}{ }^{2-}$ concentrations were 252 higher, averaging $290 \mu \mathrm{M}$ compared to $48 \mu \mathrm{M}$ in the three samples that had reported $\mathrm{SO}_{4}{ }^{2-}$ 253 concentration initially. The groundwater we sampled also generally had a higher concentration of $254 \mathrm{~K}^{+}$and dissolved $\mathrm{Mn}$ and $\mathrm{Fe}$ and a lower concentration of $\mathrm{Sr}^{2+}, \mathrm{B}^{3+}$, and $\mathrm{Ba}^{2+}$.

255 Concurrent with these compositional changes and the decline of water production, the 256 isotopic composition of the water and DIC also changed. Compared to initial samples, water $\delta \mathrm{D}$ 257 values we measured differed by more than combined analytical error $(>4 \%$ ) in samples from five 258 of the seven wells. In those samples, $\delta \mathrm{D}$ values were $11 \%$ lower on average than the values 259 measured initially (Fig. 4). In contrast to $\delta \mathrm{D}, \delta^{18} \mathrm{O}$ values were higher than initial values in nearly 260 half of the samples. Three samples had $\delta^{18} \mathrm{O}$ values that were not different from the initial values 261 by more than the combined analytical error $(>0.2 \%)$, one sample had a $\delta^{18} \mathrm{O}$ that was $0.8 \%$ 262 lower, and three samples had $\delta^{18} \mathrm{O}$ values that were $0.6 \%$ higher on average (Fig. 4). DIC $\delta^{13} \mathrm{C}$ 263 values differed by more than combined analytical error $(>0.2 \%)$ in all four samples that had 264 initial values. On average, the $\delta^{13} \mathrm{C}$ value of DIC decreased 2.7\% in two wells and increased 1\%o 265 in the other two (Supplemental Content Table SC2). 
Similar to the observed changes in water production and composition, the amount of gas $2870.735)$.

being produced and its chemical and isotopic composition has shifted since the wells were developed. Field station records show that gas production has decreased and that the proportion of $\mathrm{CO}_{2}$ in produced gas has increased by an average of $13 \mathrm{~mol} \%$ while overall natural gas production has steadily declined (Fig. 2).

Analysis of gas samples collected for this study show a similar result to the field station records. Compared to samples collected initially, the $\mathrm{CH}_{4}$ content of the gas samples we collected decreased by $11 \mathrm{~mol} \%$ on average in five wells while $\mathrm{CO}_{2}$ content increased by an equivalent amount (Supplemental Content Table SC3). Gas wetness $\left[\mathrm{C}_{1} /\left(\mathrm{C}_{2}+\mathrm{C}_{3}\right)\right]$ values in the samples were generally lower than initial values. Wetness averaged 1001 compared to 1432 initially. Although the composition of gas shifted as gas production declined, $\mathrm{CH}_{4}$ is still by far the largest component. The mean $\mathrm{CH}_{4}$ content of the samples we collected was $82 \mathrm{~mol} \%$ compared to $86 \mathrm{~mol} \%$ initially.

Shifts in the $\delta \mathrm{D}$ value of $\mathrm{CH}_{4}$ correspond to those observed in water. As the $\delta \mathrm{D}$ value of water decreased, the $\delta \mathrm{D}$ value of $\mathrm{CH}_{4}$ also largely decreased (Fig. 5A). With the exception of one sample with values that were not considerably different from those measured initially $(>4 \%$ ), the $\delta \mathrm{D}$ vales of $\mathrm{CH}_{4}$ were lower in all of the samples by $9 \%$ on average. The average difference between the $\delta \mathrm{D}$ of $\mathrm{CH}_{4}$ and water in the samples we collected was $172 \%$, which is not significantly different from the value measured initially, $171 \%$, based on a Student's T test (P

Similarly, the $\delta^{13} \mathrm{C}$ value of $\mathrm{CH}_{4}$ also decreased for most wells (Fig. 5B). One sample had $\mathrm{CH}_{4} \delta^{13} \mathrm{C}$ values that did not differ from initial values by more than combined analytical error $\left(>0.2 \%\right.$ ). The remaining six samples had $\delta^{13} \mathrm{C}$ values that were $1.3 \%$ ower on average. The $\delta^{13} \mathrm{C}$ 
291 values of $\mathrm{CO}_{2}$ measured in gas samples increased for most wells (Fig. 5B). Four samples had a

$292 \mathrm{CO}_{2} \delta^{13} \mathrm{C}$ value $1.7 \%$ higher on average. Of the remaining three samples, one did not differ from

293 initial values by more than combined analytical error $(>0.2 \%)$ and two decreased by 0.3 and

$2942.5 \%$. The fractionation factor $\left(\alpha_{c}\right)$ between $\delta^{13} \mathrm{C}$ values of $\mathrm{CO}_{2}$ and $\mathrm{CH}_{4}$ calculated for each

295 sample we collected was 1.076 on average, where $\alpha_{c}$ is expressed as:

296

$$
\alpha_{c}=\frac{\left(\delta^{13} C_{C_{2}}+1000\right)}{\left(\delta^{13} C_{C H_{4}}+1000\right)}
$$

297

298 This value is very similar to that observed in the samples collected from the wells initially, 299 1.074. Nonetheless, these averages are statistically different based on a Student's T test $(\mathrm{P}=$ $300 \quad 0.045)$.

301

302

\section{Discussion}

Our results demonstrate that considerable changes in the geochemistry and microbiology

304 of co-produced water and gas have occurred since widespread development of the Antrim

305 northern producing trend. In the sections that follow, we discuss how ongoing biogeochemical

306 reactions within the shale coupled with processes driven by commercial gas production could

307 have contributed to these changes. These findings have implications for the sustainability of

308 commercial gas production in unconventional gas reservoirs.

309

310

\subsection{Pathway of $\mathrm{CH}_{4}$ formation}

Using isotopic evidence, Martini and others $(1996 ; 1998)$ interpreted that $\mathrm{CH}_{4}$ over much

312 of the northern producing trend in the Antrim Shale was generated by $\mathrm{CO}_{2}$-reducing 
313 methanogens. The results of our isotopic analyses are consistent with those findings. Where $\mathrm{CH}_{4}$

314 is produced by $\mathrm{CO}_{2}$ reduction, the $\delta \mathrm{D}$ value of $\mathrm{CH}_{4}$ is typically about $160 \%$ o $+-10 \%$ lower than

315 the surrounding water (Nakai et al., 1974; Schoell, 1980), which is comparable to the value we

316 observed (Fig. 5A). In comparison, differences between the $\delta \mathrm{D}$ values of $\mathrm{CH}_{4}$ and water are

317 approximately twice as large where $\mathrm{CH}_{4}$ is produced by acetate fermentation (Schoell, 1980;

318 Whiticar et al., 1986; Woltemate et al., 1984). Similarly, $\mathrm{CH}_{4}$ produced by $\mathrm{CO}_{2}$ reduction is

319 generally associated with relatively high fractionation factors $\left(\alpha_{c}>1.06\right)$, comparable to those

320 we observed (Fig. 5B), whereas lower values $\left(\alpha_{c}<1.06\right)$ are typical of acetate fermentation

321 (Whiticar et al., 1986).

The results of our nucleic acid-based analysis are consistent with our interpretation based

323 on isotopic results. The dominance of phylotypes with cultured relatives that produce $\mathrm{CH}_{4}$ by

$324 \mathrm{CO}_{2}$ reduction in the archaeal clone libraries we generated suggests that $\mathrm{CO}_{2}$-reducing

325 methanogens are the most abundant Archaea in the shale. This result also compares favorably

326 with the results of previous studies that analyzed Archaea in the Antrim Shale using molecular

327 techniques. Although the clone libraries published in Formolo et al. (2008), Waldron et al.

328 (2007), and Martini et al. (2005) contained a higher percentage of clones grouping with

329 Methanosarcinales than our libraries, clones grouping in Methanomicrobiales and

330 Methanobacteriales were found to be more abundant overall than those grouping in

331 Methanosarcinales in those studies.

The relative abundance of sequences in a clone library does not necessary accurately

333 represent the abundance of the species corresponding to those sequences in the environment due

334 to both PCR (Suzuki and Giovannoni, 1996) and sampling bias (Flynn et al., 2008). Similarly,

335 interpreting pathways of microbial methanogenesis based on isotopic analysis may be less 
definitive than originally thought (e.g., Bates et al., 2011; deGraaf et al., 1996; Waldron et al., 1998). Nonetheless, both of these lines of independent evidence are in agreement, providing compelling support of our interpretation.

These findings highlight a gap in our understanding of electron flow in the Antrim Shale; the fate of acetate remains unresolved. The ultimate products of organic matter degradation generally include both acetate and $\mathrm{H}_{2}$ (Madigan et al., 2003), implying that acetate is being generated within the shale. During organic matter degradation, production of acetate relative to $\mathrm{H}_{2}$ increases as a result of the activity of acetogenic microorganisms, Bacteria that consume $\mathrm{H}_{2}$ and produce acetate. Most of the clones that grouped within the phylum Firmicutes (31 of 42; Fig. 1B) also grouped within the genus Acetobacterium based on our taxonomic analysis and indeed, a more rigorous analysis than we performed concluded that acetogens were in fact present in the northern producing trend (Formolo et al., 2008). Not only is acetate likely being generated in the shale, therefore, but its relative importance as a substrate for microbial activity may be even greater as a result of acetogenesis. Despite this, acetate has not accumulated where microbial $\mathrm{CH}_{4}$ is present (Martini et al., 2003) and $\mathrm{H}_{2}$ oxidation appears to have largely fueled formation of $\mathrm{CH}_{4}$.

This apparent lack of acetate consumption by methanogens can be explained if some group of microorganisms other than methanogens is consuming acetate. Possibilities include $\mathrm{SO}_{4}{ }^{2-}$ reducers and syntrophic acetate oxidizers. The limited availability of $\mathrm{SO}_{4}{ }^{2-}$ until recently has likely restricted the activity of $\mathrm{SO}_{4}{ }^{2-}$ reducers (see Section 4.3). Syntrophic acetate oxidizers, however, could be active within the shale where the reaction is energetically favorable.

Consistent with this possibility, clones in the library from well 150 that grouped within the Order Syntrophobacterales (Fig. 1C) also grouped within the genus Smithella based on our taxonomic 
analysis. Gray et al. (2011) found evidence that Smithella species were responsible for syntrophic acetate oxidation in methanogenic oil-degrading microcosms.

In addition to these possibilities, the apparent lack of acetate consumption by methanogens could also be explained if our isotopic and nucleic acid-based analyses underestimate $\mathrm{CH}_{4}$ contributions from acetate-fermenting methanogens or if some unknown sink for acetate exists within the shale. Uncertainty regarding the fate of acetate has also been observed in many other anoxic environments (Conrad, 1999), including unconventional gas reservoirs (e.g., Strąpoć et al., 2008). Additional research is needed to fully elucidate the pathways of electron flow through these systems.

\subsection{Shifts in archaeal community composition}

Differences in the composition of the archaeal clone libraries collected from well 150 in 2002 and 2009 suggest that the abundance of Methanosarcinales species adjacent to that well has decreased over time while the abundance of Methanobacteriales species has increased. This shift may have occurred because methanogens adjacent to the well continue to generate $\mathrm{CH}_{4}$ and changes in the environment as a result of commercial gas production favor Methanobacteriales species over Methanosarcinales species. It is also possible, however, that cells are simply being transported to the well by groundwater movement from a different zone within the subsurface than they were in 2002 (Fig. 6). In other words, a different population of planktonic cells was sampled in 2009 than 2002 because the source(s) of groundwater flowing to the well as a result of gas production has changed over time.

In addition to both of these possibilities, differences in the molecular techniques used to analyze Archaea could have also contributed to the differences in community composition. 
382 Archaeal 16S rRNA genes in the 2002 sample were amplified using a different primer set than

383 the primer set that we used, potentially leading to differences in amplification efficiency between

384 studies that may have favored Methanosarcinales species in the 2002 sample. Moreover, unlike

385 our own PCR reactions, they used nested reactions to amplify archaeal DNA, which can

386 introduce bias if too many cycles are used in the first round of amplification (Park and Crowley,

387 2010).

We examined the potential impact of differences in primer choice using the Ribosomal

389 Database Project Probe Match tool (Cole et al., 2009). The probes were tested in pairs, as they

390 were used, and the database search was restricted to sequences with data that span the

391 Escherichia coli region targeted by both sets of primers (8 to 1000). Compared to the primers we

392 used, the primers used to amplify archaeal DNA from the 2002 sample matched a much smaller

393 portion of the Methanobacteriales, Methanomicrobiales, and Methanosarcinales sequences

394 tested (Table 1). Of the three groups, furthermore, the primer set used for the 2002 sample

395 matched considerably more Methanosarcinales sequences than Methanobacteriales and

396 Methanomicrobiales sequences. These findings strongly suggest that differences in primer

397 efficiency contributed to the differences in archaeal community composition observed between

398 the 2002 and 2009 samples.

\subsection{Shifts in bacterial community composition}

Our molecular results indicate that $\mathrm{SO}_{4}{ }^{2-}$-reducing species are increasing in abundance in

402 the northern producing trend. $\mathrm{SO}_{4}{ }^{2-}$-reducing species were undetected in the analysis of the

403 sample collected from well 150 in 2002 by Martini et al. (2005) but accounted for a considerable

404 portion of our clone library for that well (Fig. 1C). Amplification conditions used in that study 
405 for Bacteria were nearly identical to those we used, implying that differences in the methods are

406 less likely to contribute to the differences observed in the bacterial clone libraries than the

407 archaeal libraries. In addition to well 150, furthermore, analysis of samples from other wells in

408 the northern producing trend also did not detect $\mathrm{SO}_{4}{ }^{2-}$ reducers using molecular techniques

409 (Formolo et al., 2008).

This shift in the composition of the bacterial community is consistent with the increase in

$411 \mathrm{SO}_{4}{ }^{2-}$ levels we observed. Where $\mathrm{SO}_{4}{ }^{2-}$ concentration exceeds as little as $30 \mu \mathrm{M}$ in freshwater

412 sediments, $\mathrm{SO}_{4}{ }^{2-}$ reducers can hold acetate and $\mathrm{H}_{2}$ concentrations below levels necessary for

413 methanogen populations to grow (Lovley and Klug, 1986; Ward and Winfrey, 1985). In saline

414 environments, this threshold may be as high as $2 \mathrm{mM}$ (Megonigal et al., 2005). Threshold

415 concentrations ranging between both extremes are likely important in the northern producing

416 trend, where the gradient in groundwater salinity is very steep (Martini et al., 1998; McIntosh et

417 al., 2002). $\mathrm{SO}_{4}{ }^{2-}$ reducers may be increasing in abundance in the shale, therefore, because $\mathrm{SO}_{4}{ }^{2-}$

418 reducers have begun to actively grow and compete with methanogens for substrates as $\mathrm{SO}_{4}{ }^{2-}$

419 concentration has increased. Similar to Archaea now present, however, groundwater movement

420 may also be transporting these cells into the shale along with $\mathrm{SO}_{4}{ }^{2-}$ from zones within the

421 subsurface that differ from those supplying water when the wells were previously sampled. Both

422 of these possibilities may contribute to the observed changes in bacterial community

423 composition.

424

425 4.4. Shifts in groundwater geochemistry

426 Our results demonstrate that the chemical and isotopic composition of water in the shale

427 has shifted considerably in most of the wells since they were initially sampled. Relatively dilute 
$428\left(\mathrm{Cl}^{-}<1 \mathrm{M}\right)$ and low- $\delta \mathrm{D}$, low- $\delta{ }^{18} \mathrm{O}$ water recharged the Antrim Shale during melting of

429 Pleistocene glaciers (McIntosh et al., 2002). Modern groundwater flow in the Great Lakes

430 region, however, is largely restricted to shallow glacial drift aquifers near the surface (McIntosh

431 et al., 2011; McIntosh and Walter, 2006). These changes within the past two decades, therefore,

432 were likely caused by groundwater inflow in response to pumping to extract natural gas rather

433 than the natural movement of groundwater in the basin.

Groundwater seeping into the Antrim likely originates from multiple sources. We

435 hypothesize that most of this inflow, however, originates from the underlying Traverse

436 Formation (Fig. 6). The distribution of aquifers and aquitards is a major control on fluid

437 migration along the Michigan Basin margin (McIntosh et al., 2002). The Antrim Shale is capped

438 by brown Mississippian shales and the Ellsworth shale, which has a much lower intrinsic

439 permeability than the Antrim (Ryder, 1996), The Antrim is underlain by Devonian carbonate

440 aquifer systems. Silurian-Devonian aquifers such as the Traverse Formation were the primary

441 path of freshwater recharge into the overlying Antrim Shale during melting of Pleistocene

442 glaciers (Eberts and George, 2000; McIntosh et al., 2002). This relatively high permeability

443 formation may also serve as the primary route of groundwater flow into the Antrim as a result of

444 commercial gas production.

Shifts in $\mathrm{SO}_{4}{ }^{2-}$ and alkalinity levels we observed support this hypothesis. The increase in

$446 \mathrm{SO}_{4}{ }^{2-}$ concentration we observed may reflect the presence of anhydrite in the Traverse Formation

447 immediately beneath the Antrim Shale. Wilson and Long (1993) measured groundwater $\mathrm{SO}_{4}{ }^{2-}$

448 levels ranging as high as $6.3 \mathrm{mM}$ with an average at $1.2 \mathrm{mM}$ in the Traverse Formation. The

449 decrease in alkalinity levels we observed is consistent with the low alkalinity content of the

450 Traverse Formation. The highest alkalinity reported by Wilson and Long (1993) was $2.6 \mathrm{mM}$ as 
$451 \mathrm{HCO}_{3}{ }^{-}$. Alkalinity levels from zones of microbial methanogensis in the Antrim Formation along

452 the northern margin of the Michigan Basin generally exceed $10 \mathrm{mM}$ (McIntosh et al., 2004).

The extent to which changes in the isotopic composition of formation water support this

454 hypothesis is less clear. The isotopic composition of water in the Michigan Basin varies widely

455 (Martini et al., 1998; McIntosh et al., 2002). This variation reflects mixing between a ${ }^{18} \mathrm{O}-$

456 enriched basin brine end-member and recharge from low- $\delta \mathrm{D}$, low- $\delta{ }^{18} \mathrm{O}$ Pleistocene glacial

457 meltwater and modern precipitation. The decrease in $\delta \mathrm{D}$ values we observed, therefore, is

458 consistent with inflow of water that has a greater proportion of meltwater and/or modern

459 precipitation than the water present when the initial samples were collected. Because the

460 Traverse Formation was a source of low $\delta \mathrm{D}$ recharge to the Antrim Shale during the Pleistocene,

461 further inflow from the Traverse would likely continue to lower $\delta \mathrm{D}$ values. Indeed isotopic

462 values reported by McIntosh et al. (2006) for the Traverse Formation along the northern edge of

463 the Michigan basin range to lower values than those we observed in the Antrim Shale (Fig. 4).

Such a shift in $\delta \mathrm{D}$ values would likely also be accompanied by a decrease in $\delta^{18} \mathrm{O}$ values.

465 This change, however, is largely inconsistent with our results. Instead, $\delta^{18} \mathrm{O}$ values were slightly

466 heavier in most cases, consistent with inflow that has a greater component of basin brine $\left(\delta^{18} \mathrm{O}-\right.$

467 enriched), such as that sampled by Wilson and Long (1993) from the Traverse Formation further

468 south within the basin (Fig. 4). These inconsistencies imply that groundwater mixing as a result

469 of pumping is not the only control on the isotopic composition of water in the shale.

Coupled with changes caused by groundwater inflow, open-system groundwater

471 degassing may have also contributed to the changes we observed. Zhou et al. (2005) showed that

472 open-system groundwater degassing as a result of commercial gas production is fractionating

473 noble gases in coal in the San Juan Basin, USA. We hypothesize that this process could also 
474 affect the isotopic composition of groundwater by extracting water vapor through unsaturated

475 pore space adjacent to the wells. Similar to evaporation, this process would enrich the isotopic

476 composition of the residual water and may have a greater impact on $\delta^{18} \mathrm{O}$ than $\delta \mathrm{D}$. Similarly,

477 open-system degassing of $\mathrm{CO}_{2}$ could also affect the composition of water by causing the $\mathrm{pH}$ of

478 aqueous solutions to increase and thereby driving precipitation of carbonate minerals and a

479 decrease in alkalinity (Dreybrodt et al., 1992). This impact would be consistent with the

480 observed decreases in alkalinity, $\mathrm{Ca}^{2+}$, and $\mathrm{Mg}^{2+}$ levels. More research is needed to fully evaluate

481 the impact that pumping has on the chemical and isotopic composition of groundwater in

482 unconventional reservoirs.

483

484

\subsection{Shift in gas geochemistry}

485

Both field station records and compositional analysis of the samples we collected

486 demonstrate that $\mathrm{CO}_{2}$ has increased relative to $\mathrm{CH}_{4}$ in the gas produced in the field area. This

487 finding is consistent with those of Martini et al. (2003), who concluded that $\mathrm{CO}_{2}$ increases over

488 time due to differences in the ability of each gas to adsorb. $\mathrm{CH}_{4}$ and $\mathrm{CO}_{2}$ compete for the same

489 adsorption sites, with $\mathrm{CO}_{2}$ being more strongly adsorbed than $\mathrm{CH}_{4}$ (Arri et al., 1992; Weniger et

490 al., 2010). As a result, the proportion of adsorption sites filled with $\mathrm{CO}_{2}$ increases as formation

491 pressure decreases during commercial gas production, ultimately causing $\mathrm{CO}_{2}$ to account for an

492 increasing proportion of the produced gas.

493 As the proportion of $\mathrm{CO}_{2}$ has increased, our results show that the isotopic composition of

$494 \mathrm{CO}_{2}$ and $\mathrm{CH}_{4}$ has shifted. Similar to the observed shifts in water geochemistry and microbiology,

495 these shifts may have occurred because gas is being drawn into each well from a different

496 location than it was when the initial samples were collected. Like water, the isotopic composition 
497 of gas varies sharply in the Antrim Shale along the northern edge of the basin (McIntosh et al., 498 2004). Drawing gas from different zones over time, therefore, would cause the isotopic 499 composition of produced gas to shift. Parallel shifts in the $\delta \mathrm{D}$ values of water and $\mathrm{CH}_{4}$ that we 500 observed are consistent with this interpretation. The fractionation factor between water and $\mathrm{CH}_{4}$ 501 remained constant as the $\delta \mathrm{D}$ of water changed, providing evidence that the co-produced water 502 was present when the $\mathrm{CH}_{4}$ formed. The water and gas, therefore, may have been drawn toward 503 the well simultaneously from the same location.

In addition to changes in gas source, many other processes may have also contributed to 505 changes in the isotopic composition of $\mathrm{CO}_{2}$ and $\mathrm{CH}_{4}$ including fractionation associated with 506 desorption and continued microbial activity. Light isotopologues generally desorb more easily 507 and have higher diffusion coefficients than heavy isotopologues (Xia and Tang, 2012; Zhang and 508 Krooss, 2001). These processes would cause the gas to get heavier over time during commercial 509 production as light isotopologues would be withdrawn preferentially following initial 510 development of a reservoir. This process may indeed explain the observed shift in the $\delta^{13} \mathrm{C}$ of $511 \mathrm{CO}_{2}$ but not $\mathrm{CH}_{4}$, possibly reflecting differences in the extent to which those gases adsorb to 512 organic matter. A recent study concluded that $\mathrm{CH}_{4}$ fractionation in response to adsorption and 513 diffusion is limited under geological conditions (Xia and Tang, 2012). If this is true for $\mathrm{CH}_{4}$ but 514 not $\mathrm{CO}_{2}$, then it could at least partially explain the changes in $\alpha$ between the recent and initial 515 samples.

516 Continued microbial activity could have contributed to changes in the isotopic 517 composition of $\mathrm{CO}_{2}$ and $\mathrm{CH}_{4}$ by generating both $\mathrm{CO}_{2}$ and $\mathrm{CH}_{4}$ under conditions that are more 518 consistent with an open system than they were before development. The decrease in the $\delta^{13} \mathrm{C}$ of $519 \mathrm{CO}_{2}$ produced from wells 73 and $\mathrm{B}$ is consistent with $\mathrm{CO}_{2}$ generation within the last 20 years. 
520 Unless $\mathrm{CO}_{2}$ is simply being drawn into those wells from a zone with $\mathrm{CO}_{2}$ that has a lower $\delta^{13} \mathrm{C}$

521 than the $\mathrm{CO}_{2}$ that was initially present, additional $\mathrm{CO}_{2}$ must have been generated that has a $\delta^{13} \mathrm{C}$

522 more consistent with organic matter (i.e., lower). Parallel shifts in the $\delta^{13} \mathrm{C}_{\text {of }} \mathrm{CO}_{2}$ and $\mathrm{CH}_{4}$ and

523 the $\delta \mathrm{D}$ of water and $\mathrm{CH}_{4}$ are consistent with continued $\mathrm{CH}_{4}$ formation in wells 147 and $\mathrm{B}$. If

524 methanogenesis continues to occur at a significant rate in the volume sampled by those wells,

525 changes in the isotopic composition of $\mathrm{CH}_{4}$ there would be consistent with changes in the

526 isotopic composition of both $\mathrm{CO}_{2}$ and water.

527 Unlike the possibilities outline above, $\mathrm{CH}_{4}$ oxidation does not appear to be a primary 528 control on the isotopic composition of either $\mathrm{CH}_{4}$ or $\mathrm{CO}_{2}$. During $\mathrm{CH}_{4}$ oxidation, isotopically 529 depleted $\mathrm{CH}_{4}$ is preferentially oxidized (Barker and Fritz, 1981; Holler et al., 2009). This effect 530 would increase the $\delta^{13} \mathrm{C}$ value of residual $\mathrm{CH}_{4}$ and decrease the $\delta^{13} \mathrm{C}$ value of $\mathrm{CO}_{2}$, the opposite 531 of what we observed in most wells.

532

\subsection{Potential impact of hydraulic fracturing}

Hydraulic fracturing within the wells we sampled does not appear to have caused the

535 changes in geochemistry and microbiology that we observed. Each of the wells included in this

536 study were stimulated soon after the wells were drilled (Supplemental Content Table SC1).

537 Stimulation was accomplished using nitrogen foam, acid solutions, and sand; an approach used

538 in many other wells in the northern producing trend of the Antrim Shale (Milici, 1993). All of

539 the samples collected initially from the wells included in this study were collected at least 3

540 months after stimulation. Moreover, there is no record of well re-working for any of the wells

541 between the initial sampling dates and the final sampling dates based on personal communication 
542 with well operators and well records obtained from the Michigan Department of Environmental 543 Quality.

544 If wells were completed near those we sampled during the period of time between

545 collection of our initial and final samples, however, it is possible that hydraulic fracturing could

546 have caused some of the changes we observed. The water, chemicals, and dissolved gases

547 injected into the shale for hydraulic fracturing could have ultimately mixed with pore water

548 flowing to the wells we sampled via natural and induced fractures. Considering the potential that

549 this process has to impact biological processes within shale-gas reservoirs, future research is

550 warranted to examine the biological implications of hydraulic fracturing in more detail.

551

552

553

554

555

556

557

558

559

560 561 degassing.

562

563

564

\section{Conclusions}

Our results show that (1) gas being commercially produced in the field area today was still primarily produced by $\mathrm{CO}_{2}$ reduction, (2) $\mathrm{SO}_{4}{ }^{2-}$ concentration and the abundance of $\mathrm{SO}_{4}{ }^{2-}-$ reducing microorganisms have increased, changes that may ultimately allow $\mathrm{SO}_{4}{ }^{2-}$ reducers to displace methanogens, and (3) in addition to $\mathrm{SO}_{4}{ }^{2-}$, other changes in the chemical and isotopic composition of water and gas in the shale have also occurred. These changes in microbiology and geochemistry can be explained by ongoing biogeochemical reactions and processes driven by commercial gas production, including groundwater flow, gas desorption, and open-system

These findings highlight the complex array of processes that can influence geochemistry and microbiology during commercial gas production and multiple areas where additional research is needed. These findings also have important implications for commercial gas 
565 production. They imply that the practices used currently for commercial gas production from

566 fractured shale can ultimately shorten the lifespan of an unconventional natural gas play by

567 creating conditions that favor growth of microorganisms that can compete with methanogens for

568 substrates. Future development in unconventional gas reservoirs should consider the chemical

569 composition of water in adjacent formations and the potential of those formations to serve as a

570 source of water inflow in response to pumping.

571

572 Acknowledgements

573 We thank members of the Gas Technology Institute New Albany Shale consortium for

574 helpful comments and reviews. We are grateful to two anonymous reviewers for helpful

575 comments that improved this manuscript. We also thank Thomas Naughton and the personnel of

576 energy companies that assisted us with field work, Maarten de Moor and Zach Sharp for helpful

577 discussions, and Tim Maness for field station data. This work was supported by both RPSEA

578 funding through the Ultra-Deepwater and Unconventional Natural Gas and Other Petroleum

579 Resources program and the American Chemical Society-Petroleum Research Fund grant to

580 Martini.

581

582 References

583 Arri, L.E., Yee, D., Morgan, W.D., Jeansomme, M.W., 1992. Modeling coalbed methane production with 584 binary gas sorption. Paper 24363, Society of Petroleum Engineers.

585 Barker, J.F., Fritz, P., 1981. Carbon isotope fractionation during microbial methane oxidation. Nature, $586 \quad 293,289-291$. 
Bates, B.L., McIntosh, J.C., Lohse, K.A., Brooks, P.D., 2011. Influence of groundwater flowpaths, residence times and nutrients on the extent of microbial methanogenesis in coal beds: Powder River Basin, USA. Chem. Geol., 284, 45-61.

Bonin, A.S., Boone, D.R., 2006. The Order Methanobacteriales, in: Dworkin, M., Falkow, S., Rosenberg, E., Schleifer, K.-H., Stackebrandt, E. (Eds.), The Prokaryotes. Springer, Singapore, pp. 231-243.

Cole, J.R., Wang, Q., Cardenas, E., Fish, J., Chai, B., Farris, R.J., Kulam-Syed-Mohideen, A.S., McGarrell, D.M., Marsh, T., Garrity, G.M., Tiedje, J.M., 2009. The Ribosomal Database Project: improved alignments and new tools for rRNA analysis. Nucleic Acids Res., 37, D141-D145.

Conrad, R., 1999. Contribution of hydrogen to methane production and control of hydrogen concentrations in methanogenic soils and sediments. Fems. Microbiol. Ecol., 28, 193-202.

Craig, H., 1961. Isotopic variations in meteoric waters. Science, 133, 1702-1703.

Curtis, J.B., 2002. Fractured shale-gas systems. AAPG Bull., 86, 1921-1938.

deGraaf, W., Wellsbury, P., Parkes, R.J., Cappenberg, T.E., 1996. Comparison of acetate turnover in methanogenic and sulfate-reducing sediments by radiolabeling and stable isotope labeling and by use of specific inhibitors: Evidence for isotopic exchange. Appl. Environ. Microbiol., 62, 772777.

DeSantis, T.Z., Hugenholtz, P., Keller, K., Brodie, E.L., Larsen, N., Piceno, Y.M., Phan, R., Andersen, D.T., 2006a. NAST: a multiple sequence alignment server for comparitive analysis of 16S rRNA genes. Nucleic Acids Res., 34, W394-W399.

DeSantis, T.Z., Hugenholtz, P., Larsen, N., Rojas, M., Brodie, E.L., Keller, K., Huber, T., Dalevi, D., Hu, P., Andersen, G.L., 2006b. Greengenes, a chimera-checked 16S rRNA gene database and workbench compatible with ARB. Appl. Environ. Microbiol., 72, 5069-5072.

Dreybrodt, W., Buhmann, D., Michaelis, J., Usdowski, E., 1992. Geochemically controlled calcite precipitation by $\mathrm{CO}_{2}$ outgassing: Field measurements of precipitation rates in comparison to theoretical predictions. Chem. Geol., 97, 285-294. 
Eberts, S.M., George, L.L., 2000. Regional groundwater flow and geochemistry in the Midwestern basins and arches aquifer system in parts of Indian, Ohio, Michigan, and Illinois, U.S. Geological Survey Professional Paper 1423-C.

Flores, R.M., Rice, C.A., Stricker, G.D., Warden, A., Ellis, M.S., 2008. Methanogenic pathways of coalbed gas in the Powder River Basin, United States: The geologic factor. Int. J. Coal Geol., 76, 5275.

Flynn, T.M., Sanford, R.A., Bethke, C.M., 2008. Attached and suspended microbial communities in a pristine confined aquifer. Water Resour. Res., 44, 1-7.

Formolo, M.J., Salacup, J.M., Petsch, S.T., Martini, A.M., Nusslein, K., 2008. A new model linking atmospheric methane sources to Pleistocene glaciation via methanogenesis in sedimentary basins. Geology, 36, 139-142.

Garcia, J.-L., Ollivier, B., Whitman, W.B., 2006. The Order Methanomicrobiales, in: Dworkin, M., Falkow, S., Rosenberg, E., Schleifer, K.-H., Stackebrandt, E. (Eds.), The Prokaryotes. Springer, Singapore, pp. 208-230.

Garrity, G.M., Brenner, D.J., Krieg, N.R., Staley, J.T. (Eds.), 2005. Bergey's Manual of Systematic Bacteriology. (Vol. 2) The Proteobacteria, (Part C) The Alpha-, Beta-, Delta-, and Epsilonproteobacteria, 2. Springer, New York, NY, 925-926 pp.

Giovannoni, S.J., Delong, E.F., Schmidt, T.M., Pace, N.R., 1990. Tangential Flow Filtration and Preliminary Phylogenetic Analysis of Marine Picoplankton. Appl. Environ. Microbiol., 56, 25722575 .

Gray, N.D., Sherry, A., Grant, R.J., Rowan, A.K., Hubert, C.R.J., Callbeck, C.M., Aitken, C.M., Jones, D.M., Adams, J.J., Larter, S.R., Head, I.M., 2011. The quantitative significance of Syntrophaceae and syntrophic partnerships in methanogenic degradation of crude oil alkanes. Environ. Microbiol., 13, 2957-2975. 
Grosskopf, R., Janssen, P.H., Liesack, W., 1998. Diversity and structure of the methanogenic community in anoxic rice paddy soil microcosms as examined by cultivation and direct 16S rRNA gene sequence retrieval. Appl. Environ. Microbiol., 64, 960-969.

Holler, T., Wegener, G., Knittel, K., Boetius, A., Brunner, B., Kuypers, M.M.M., Widdel, F., 2009. Substantial C-13/C-12 and D/H fractionation during anaerobic oxidation of methane by marine consortia enriched in vitro. Environ. Microbiol. Rep., 1, 370-376.

Hughes, J.B., Hellmann, J.J., Ricketts, T.H., Bohannan, B.J.M., 2001. Counting the uncountable: Statistical approaches to estimating microbial diversity. Appl. Environ. Microbiol., 67, 43994406.

Jin, Q., Bethke, C.M., 2007. The thermodynamics and kinetics of microbial metabolism. Am. J. Sci., 307, 643-677.

Lovley, D.R., Klug, M.J., 1986. Model for the distribution of sulfate reduction and methanogenesis in freshwater sediments. Geochim. Cosmochim. Acta, 50, 11-18.

Madigan, M.T., Martinko, J.M., Parker, J., 2003. Brock Biology of Microorganisms, tenth ed. Pearson Education, Inc., Upper Saddle River.

Martini, A.M., Budai, J.M., Walter, L.M., Schoell, M., 1996. Microbial generation of economic accumulations of methane within a shallow organic-rich shale. Nature, 383, 155-158.

Martini, A.M., Nusslein, K., Petsch, S., 2005. Enhancing microbial gas from unconventional reservoirs, GasTIPS. Available at: http://www.netl.doe.gov/technologies/oilgas/publications/GasTIPS/GasTips-Spring2005.pdf. Hart Energy Publishing, LP, pp. 3-7. Martini, A.M., Walter, L.M., Budai, J.M., Ku, T.C.W., Kaiser, C.J., Schoell, M., 1998. Genetic and temporal relations between formation waters and biogenic methane: Upper Devonian Antrim Shale, Michigan Basin, USA. Geochim. Cosmochim. Acta, 62, 1699-1720. 
Martini, A.M., Walter, L.M., Ku, T.C.W., Budai, J.M., McIntosh, J.C., Schoell, M., 2003. Microbial production and modification of gases in sedimentary basins: A geochemical case study from a Devonian shale gas play, Michigan basin. AAPG Bull., 87, 1355-1375.

McIntosh, J., Martini, A., Petsch, S., Huang, R., Nusslein, K., 2008. Biogeochemistry of the Forest City Basin coalbed methane play. Int. J. Coal Geol., 76, 111-118.

McIntosh, J.C., Garven, G., Hanor, J.S., 2011. Impacts of Pleistocene glaciation on large-scale groundwater flow and salinity in the Michigan Basin. Geofluids, 11, 18-33.

McIntosh, J.C., Walter, L.M., 2006. Paleowaters in Silurian-Devonian carbonate aquifers: Geochemical evolution of groundwater in the Great Lakes region since the Late Pleistocene. Geochim. Cosmochim. Acta, 70, 2454-2479.

McIntosh, J.C., Walter, L.M., Martini, A.M., 2002. Pleistocene recharge to midcontinent basins: Effects on salinity structure and microbial gas generation. Geochim. Cosmochim. Acta, 66, 1681-1700.

McIntosh, J.C., Walter, L.M., Martini, A.M., 2004. Extensive microbial modification of formation water geochemistry: Case study from a Midcontinent sedimentary basin, United States. Geol. Soc. Am. Bull., 116, 743-759.

Megonigal, J.P., Hines, M.E., Visscher, P.T., 2005. Anaerobic metabolism: linkages to trace gases and aerobic processes, in: Schlesinger, W.H., Holland, H.D., Turekian, K.K. (Eds.), Treatise on Geochemistry. Treatise on Geochemistry. Elsevier, Amsterdam, pp. 319-424.

Milici, R.C., 1993. Autogenic gas (self-sourced) from shales - An example from the Appalachain Basin, U.S. Geological Survey Professional Paper 1570, Washington DC.

Moore, E.R.B., Tindall, B.J., Martins Dos Santos, V.A.P., Pieper, D.H., Ramos, J.-L., Palleroni, N.J., 2006. Nonmedical: Pseudomonas, in: Dworkin, M., Falkow, S., Rosenberg, E., Schleifer, K.-H., Stackebrandt, E. (Eds.), The Prokaryotes. Springer, New York, pp. 646-703.

Nakai, N., Yoshida, Y., Ando, N., 1974. Isotopic studies on oil and natural gas fields in Japan. Chikyu Kagaku, 7/8, 87-89. 
NETL, 2009. Modern Shale Gas Development in the United States: A Primer. Available at: http://www.netl.doe.gov/technologies/oil-gas/publications/epreports/shale_gas_primer_2009.pdf. U.S. Department of Energy.

Park, J.W., Crowley, D.E., 2010. Nested PCR bias: a case study of Pseudomonas spp. in soil microcosms. J. Environ. Monit., 12, 985-988.

Ryder, R.T., 1996. Fracture patterns and their origin in the Upper Devonian Antrim Shale gas reservoir of the Michigan basin: A review. Open-File Report 96-23, U.S. Geological Survey, Reston, Virginia.

Schlegel, M.E., McIntosh, J.C., Bates, B.L., Kirk, M.F., Martini, A.M., 2011. Comparison of fluid geochemistry and microbiology of multiple organic-rich reservoirs in the Illinois Basin, USA: Evidence for controls on methanogenesis and microbial transport. Geochim. Cosmochim. Acta, 75, 1903-1919.

Schloss, P.D., Westcott, S.L., Ryabin, T., Hall, J.R., Hartmann, M., Hollister, E.B., Lesniewski, R.A., Oakley, B.B., Parks, D.H., Robinson, C.J., Sahl, J.W., Stres, B., Thallinger, G.G., Van Horn, D.J., Weber, C.F., 2009. Introducing mothur: open-source, platform-independent, communitysupported software for describing and comparing microbial communities. Appl. Environ. Microbiol., 75, 7537-7541.

Schoell, M., 1980. The hydrogen and carbon isotopic composition of methane from natural gases of various origins. Geochim. Cosmochim. Acta, 44, 649-661.

Scott, A.R., Kaiser, W.R., Ayers, W.B., 1994. Thermogenic and secondary biogenic gases, San Juan Basin, Colorado and New Mexico - Implications for coalbed gas producibility. Bull. Am. Assoc. Petrol. Geol., 78, 1186-1209.

Strąpoć, D., Picardal, F.W., Turich, C., Schaperdoth, I., Macalady, J.L., Lipp, J.S., Lin, Y.S., Ertefai, T.F., Schubotz, F., Hinrichs, K.U., Mastalerz, M., Schimmelmann, A., 2008. Methane-producing 
725

726

microbial community in a coal bed of the Illinois Basin. Appl. Environ. Microbiol., 74, 24242432.

Su, X.B., Lin, X.Y., Liu, S.B., Zhao, M.J., Song, Y., 2005. Geology of coalbed methane reservoirs in the Southeast Qinshui basin of China. Int. J. Coal Geol., 62, 197-210.

Suzuki, M.T., Giovannoni, S.J., 1996. Bias caused by template annealing in the amplification of mixtures of 16S rRNA genes by PCR. Appl. Environ. Microbiol., 62, 625-630.

Takacs-Vesbach, C., Reysenbach, A.-L., Boone, D.R., 2001. Archaeal Ecology, Encyclopedia of Life Sciences. Nature Publishing Group.

Waldron, P.J., Petsch, S.T., Martini, A.M., Nuslein, K., 2007. Salinity constraints on subsurface archaeal diversity and methanogenesis in sedimentary rock rich in organic matter. Appl. Environ. Microbiol., 73, 4171-4179.

Waldron, S., Watson-Craik, I.A., Hall, A.J., Fallick, A.E., 1998. The carbon and hydrogen stable isotope composition of bacteriogenic methane: A laboratory study using a landfill inoculum. Geomicrobiol. J., 15, 157-169.

Walter, L.M., Budai, J.M., Abriola, L.M., Stearns, C.H., Martini, A.M., Ku, T.C.W., 1996. Hydrogeochemistry of the Antrim Shale, northern Michigan Basin, Gas Research Institute, 95/0251.

Wang, Q., Garrity, G.M., Tiedje, J.M., Cole, J.R., 2007. Naive Bayesian classifier for rapid assignment of rRNA sequences into the new bacterial taxonomy. Appl. Environ. Microbiol., 73, 5261-5267.

Ward, D.M., Winfrey, M.R., 1985. Interactions between methanogenic and sulfate-reducing bacteria in sediments. Adv. Aquat. Microbiol., 3, 141-179.

Warwick, P.D., Breland, F.C., Hackley, P.C., 2008. Biogenic origin of coalbed gas in the northern Gulf of Mexico Coastal Plain, USA. Int. J. Coal Geol., 76, 119-137.

Weniger, P., Kalkreuth, W., Busch, A., Krooss, B.M., 2010. High-pressure methane and carbon dioxide sorption on coal and shale samples from the Parana Basin, Brazil. Int. J. Coal Geol., 84, 190-205. 
White, C.M., Strazisar, B.R., Granite, E.J., Hoffman, J.S., Pennline, H.W., 2003. Separation and capture of $\mathrm{CO}_{2}$ from large stationary sources and sequestration in geological formations - Coalbeds and deep saline aquifers. J. Air Waste Manage. Assoc., 53, 645-715.

Whiticar, M.J., Faber, E., Schoell, M., 1986. Biogenic methane formation in marine and fresh-water environments $-\mathrm{CO}_{2}$ reduction vs acetate fermentation isotope evidence. Geochim. Cosmochim. Acta, 50, 693-709.

Wilson, T.P., Long, D.T., 1993. Geochemistry and isotope chemistry of Michigan Basin brines Devonian formations. Appl. Geochem., 8, 81-100.

Woltemate, I., Whiticar, M.J., Schoell, M., 1984. Carbon and hydrogen isotopic composition of bacterial methane in a shallow fresh-water lake. Limnol. Ocean., 29, 985-992.

Xia, X., Tang, Y., 2012. Isotope fractionation of methae during natural gas flow with coupled diffusion and adsorption/desorption. Geochim. Cosmochim. Acta, 77, 489-503.

Zhang, T.W., Krooss, B.M., 2001. Experimental investigation on the carbon isotope fractionation of methane during gas migration by diffusion through sedimentary rocks at elevated temperature and pressure. Geochim. Cosmochim. Acta, 65, 2723-2742.

Zhou, Z., Ballentine, C.J., Kipfer, R., Schoell, M., Thibodeaux, S., 2005. Noble gas tracing of groundwater/coalbed methane interaction in the San Juan Basin, USA. Geochim. Cosmochim. Acta, 69, 5413-5428. 
Figures

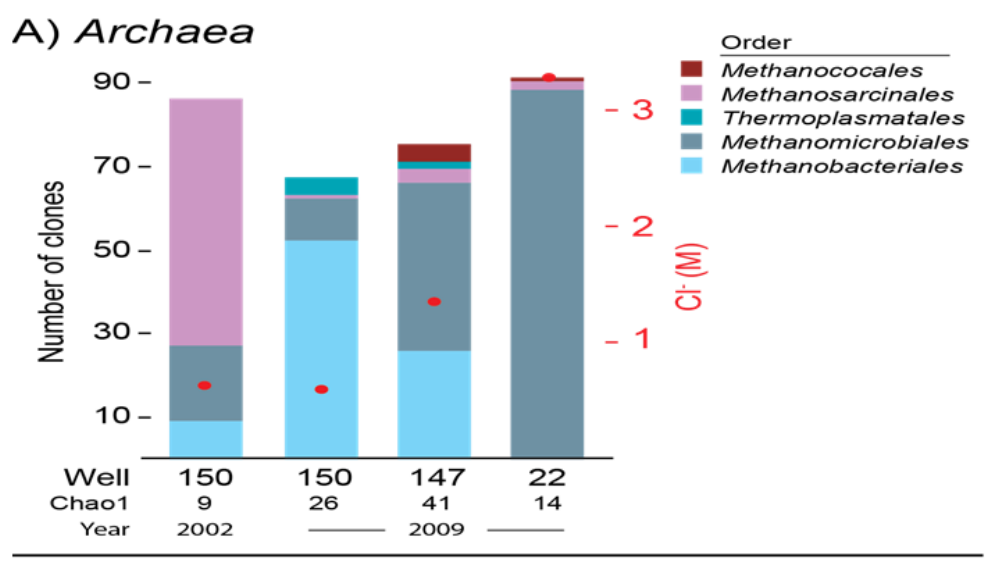

B) Bacteria

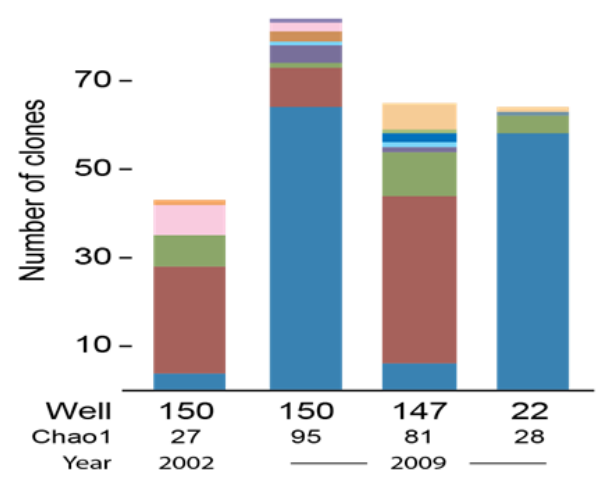

Phylum

Inclassified

- Chlorobi

- Chlorobi

- Acidobacteria

- Synergistetes

- Actinobacteria

- Chloroflexi

- Caldiserica

- Bacteroidetes

- Firmicutes

- Proteobacteria

\section{C) Proteobacteria}

757 Figure 1. Taxonomic distribution of clones detected in samples from well 150, 147, and 22.

758 Chart (A) shows the distribution of archaeal clones at the order level, (B) shows bacterial clones

759 at the phylum level, and (C) shows proteobacterial clones at the order level. Chaol richness

760 estimates based on OTUs defined at $\geq 97 \%$ sequence identity are listed for each library under the

761 charts for Archaea and Bacteria. $\mathrm{Cl}^{-}$concentration is plotted on the chart showing Archaea. 
$\underline{\text { Figure } 2}$
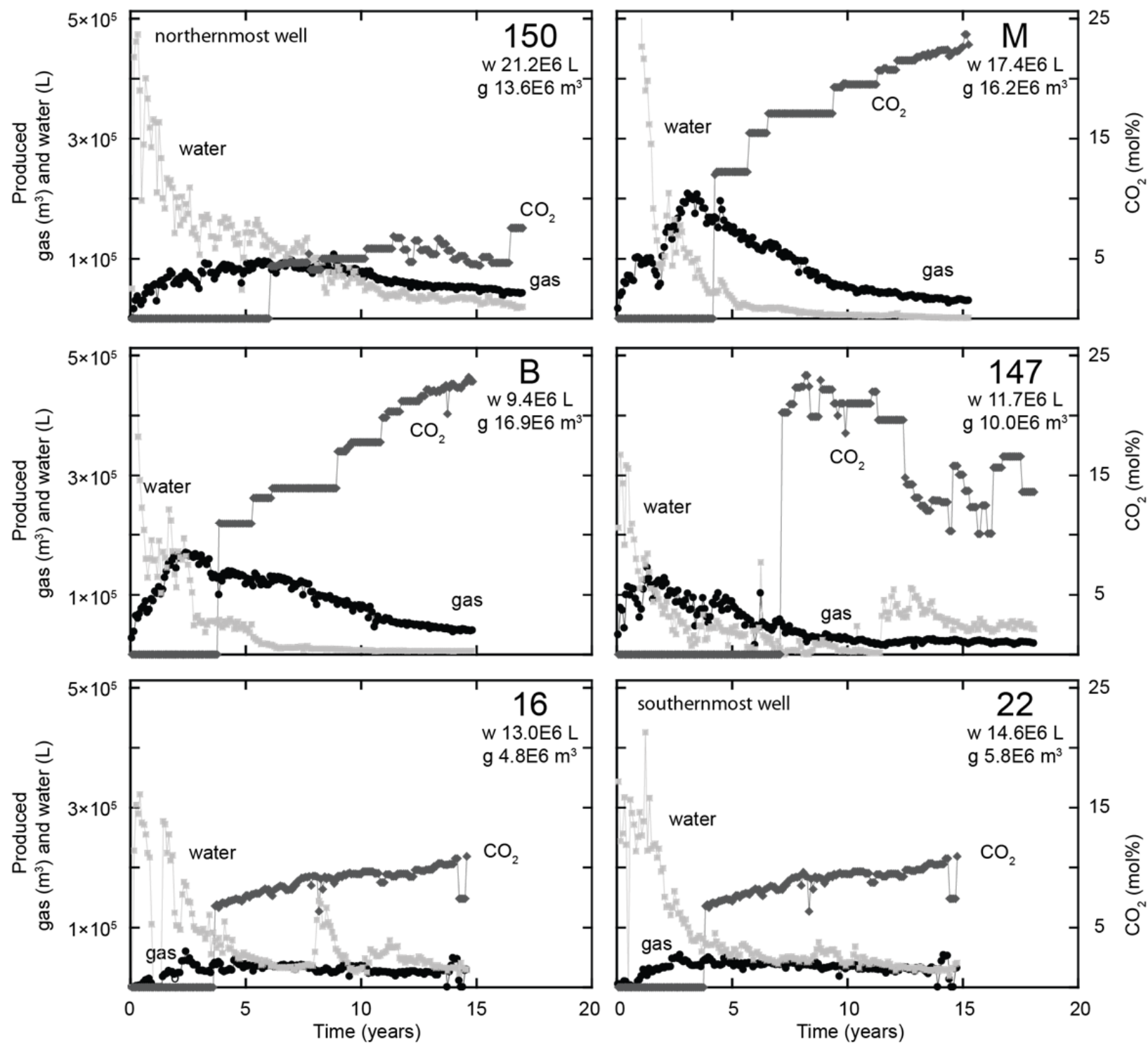

Figure 2. Variation in water and gas production and gas $\mathrm{CO}_{2}$ content over time at field stations supplied by wells $150, \mathrm{M}, \mathrm{B}, 147,16$, and 22 . Data are plotted relative to the date each field station came online $(\mathrm{t}=0)$ and normalized to the number of wells in the field. The graphs are

767 ordered from north to south as indicated on the figure. Cumulative water (w) and gas (g)

768 volumes produced at each field station are provided in the upper right corner of each figure.

769 These values are also normalized to the number of wells in the field. 
Figure 3
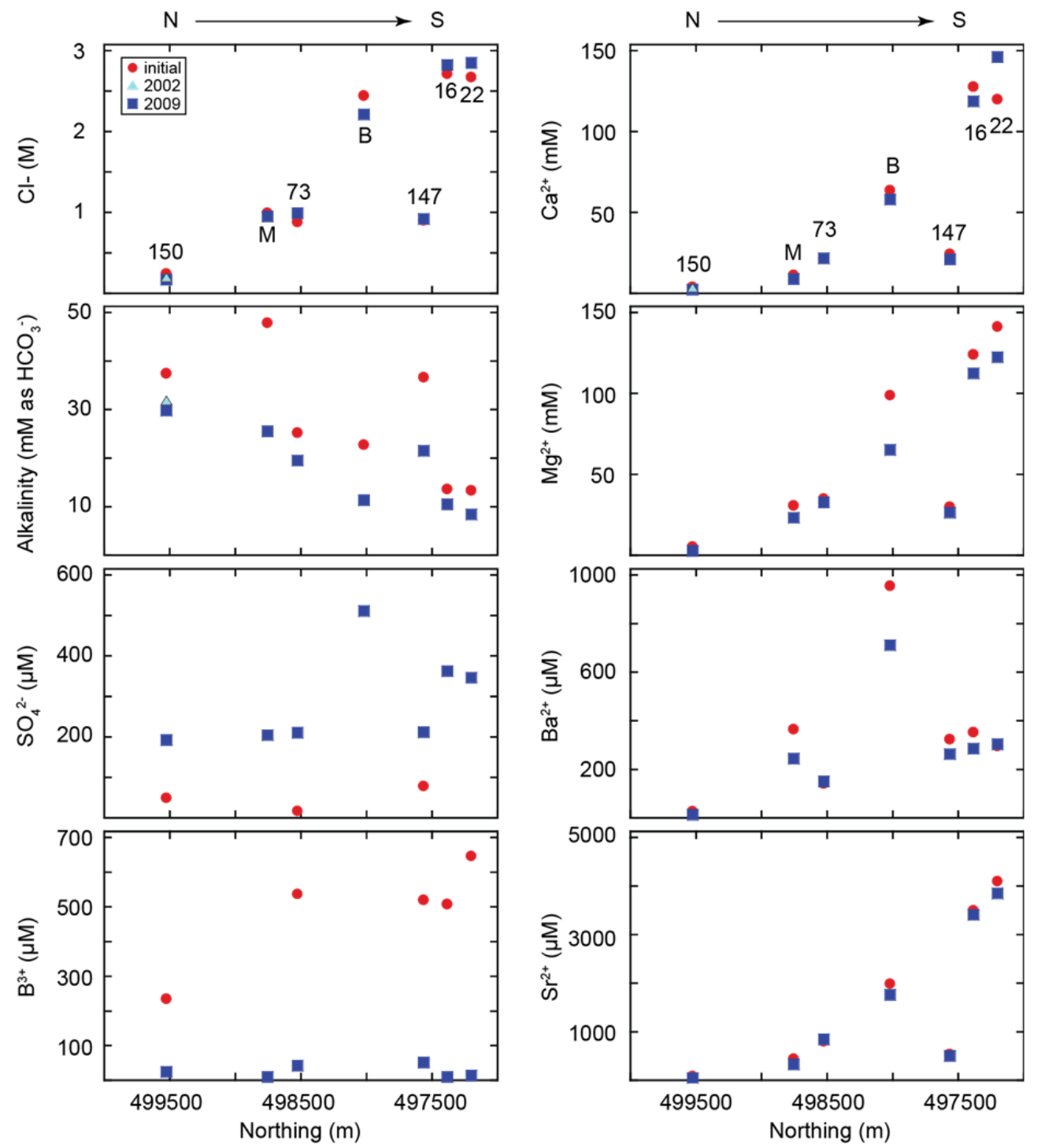

772 Figure 3. Variation in aqueous chemistry with distance north to south.

773 


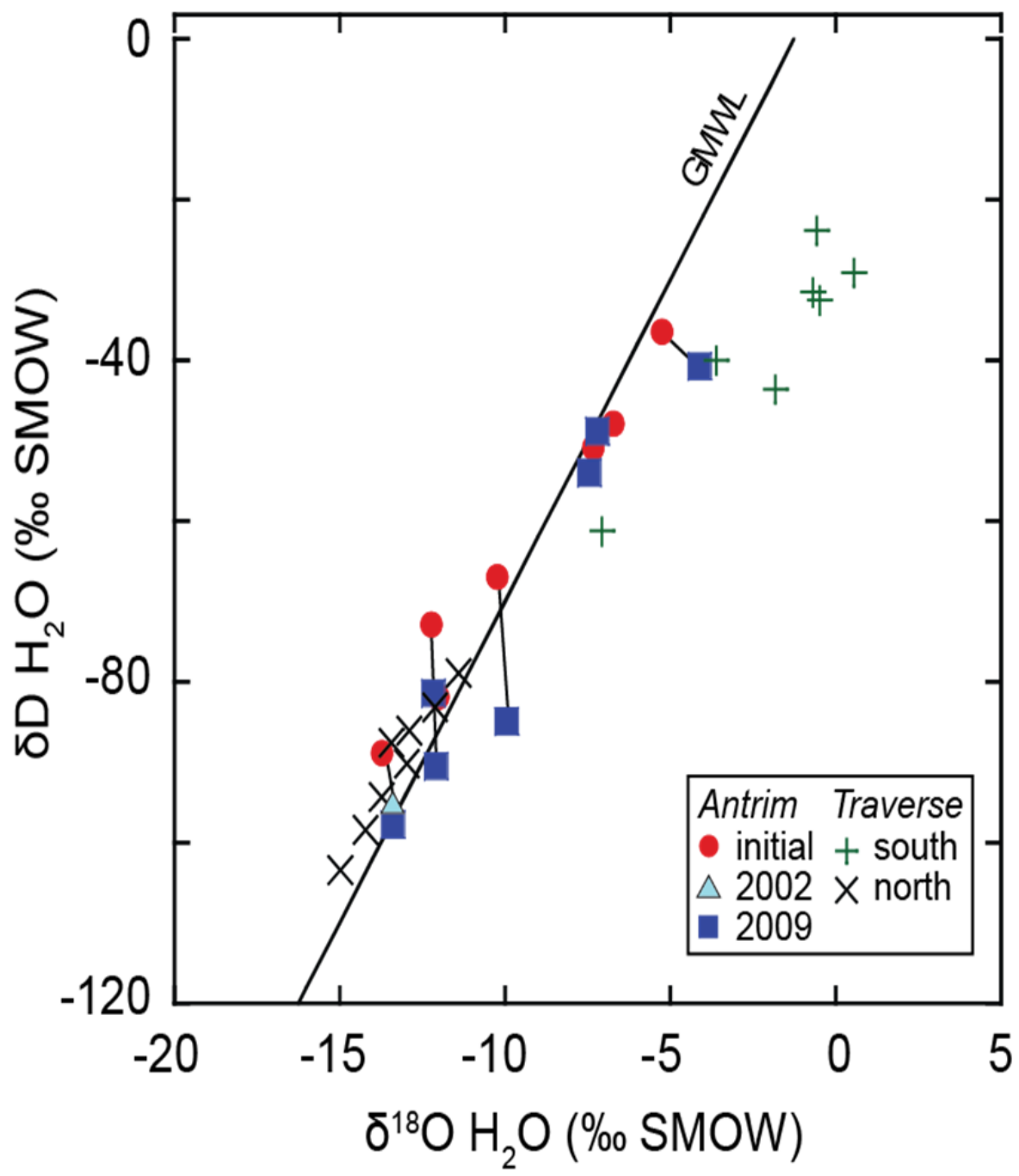

776 Figure 4. Variation in the isotopic composition of water relative to the global meteoric water line

777 (GMWL; Craig, 1961). Also plotted are data collected from the Traverse Formation along the 778 northern margin of the basin by McIntosh and Walter (2006) and further south by Wilson and 779 Long (1993). 

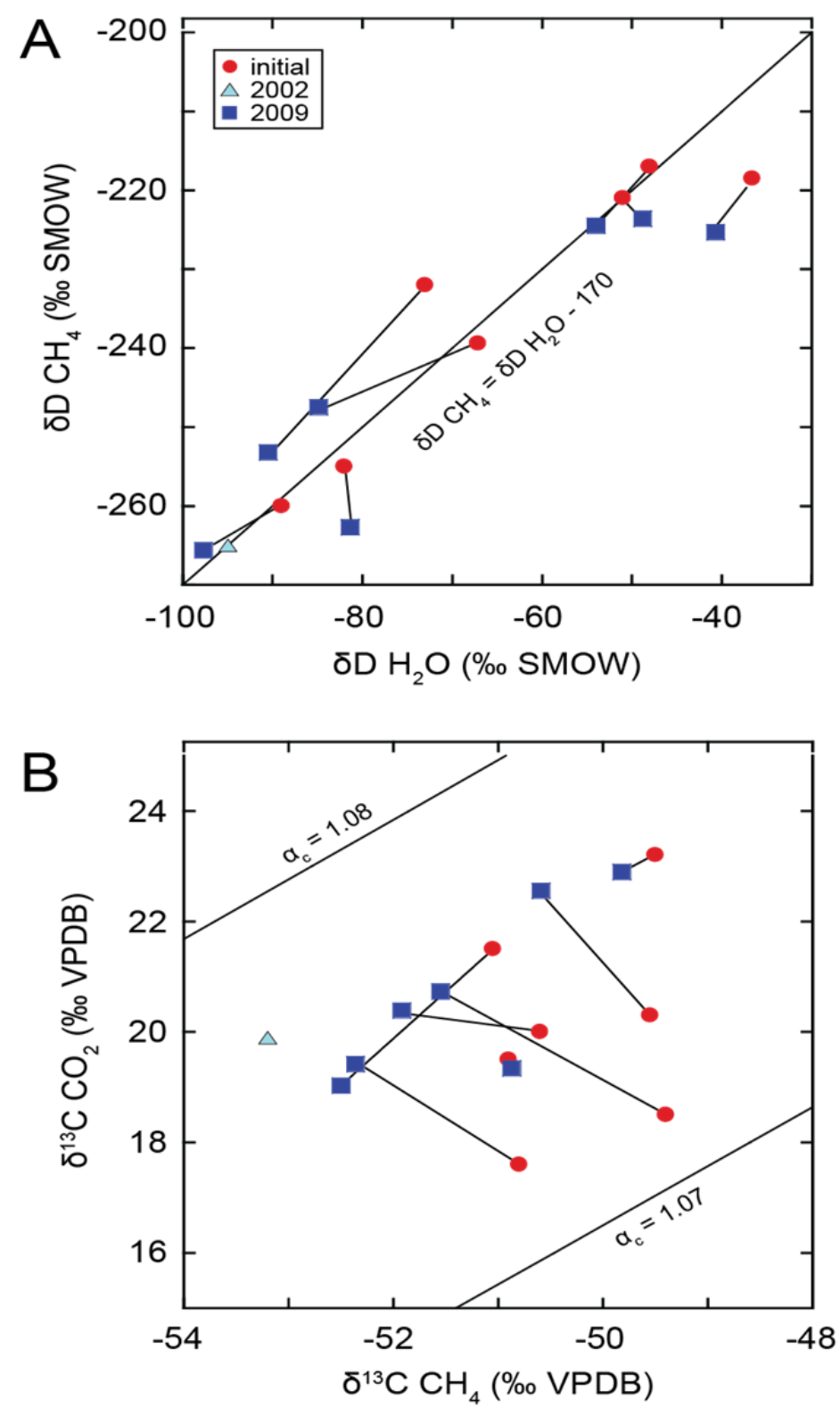

782

783 Figure 5. Variation in (A) the hydrogen isotope composition of $\mathrm{CH}_{4}$ relative to co-produced

784 water and (B) the carbon isotope composition of $\mathrm{CH}_{4}$ relative to $\mathrm{CO}_{2}$. The $\delta \mathrm{D}$ value of $\mathrm{CH}_{4}$ was

785 lower than the $\delta \mathrm{D}$ value of water by $172 \%$ (samples collected in 2009 ) and $171 \%$ (samples collected

786 initially), on average. The average fractionation factor $\left(\alpha_{c}\right)$ between $\mathrm{CO}_{2}$ and $\mathrm{CH}_{4}$ carbon

787 isotopes was 1.076 in 2009 samples and 1.074 in the samples collected initially. 


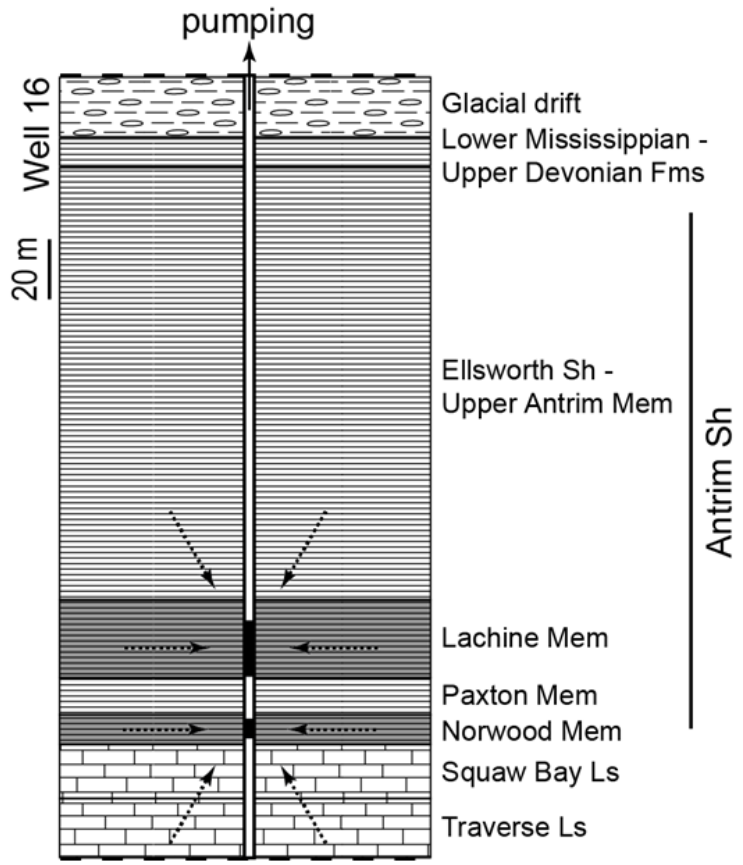

790 Figure 6. Schematic showing possible sources of groundwater inflow into the Antrim Shale as a

791 result of pumping. The stratigraphy shown was interpreted from electric well logs for well 16

792 (Walter et al., 1996) and is similar to the stratigraphy observed in all of the wells we sampled.

793 The Lachine and Norwood Members of the Antrim Shale have the highest organic matter content

794 (0.5-24 wt.\% TOC) and are the main targets for commercial gas production (Martini et al.,

795 1998). Well perforations coinciding with the depth of these members are shown in black in the

796 well bore. The upper Devonian and lower Mississippian formations above the Antrim include the

797 Coldwater, Red Rock, Sunbury, Berea, and Bedford. The glacial drift is $202 \mathrm{~m}$ thick at the well

798 site and the Traverse Limestone exceeds $66 \mathrm{~m}$ in thickness. The Ellsworth Shale has a much

799 larger fracture spacing than the Antrim, Squaw Bay, and Traverse formations (Ryder, 1996). As

800 a result, the Ellsworth has a lower intrinsic permeability, which likely limits groundwater flow

801 from that formation as a result of pumping. 
Table 1. Results of probe match analysis

\begin{tabular}{lccccccc} 
& Total $^{1}$ & & \multicolumn{2}{c}{2002 sample $^{2}$} & & \multicolumn{2}{c}{2009 sample $^{3}$} \\
\cline { 7 - 8 } \cline { 7 - 8 } Order & sequences & matches & $\%$ & & matches & $\%$ \\
\hline Methanobacteriales & 189 & 29 & $15 \%$ & & 168 & $89 \%$ \\
Methanomicrobiales & 563 & 34 & $6 \%$ & & 520 & $92 \%$ \\
Methanosarcinales & 999 & 322 & $32 \%$ & & 813 & $81 \%$ \\
\hline
\end{tabular}

${ }^{1}$ Analysis performed using the Ribosomal Database Project Probe Match tool (Cole et al., 2009) with the database restricted to sequences containing data in the E. coli region from 8 to 1000 .

${ }^{2}$ Archaeal DNA amplified using 25F (5'-CYG GTT GAT CCT GCC RG-3') AND 958R (5'-YCC GGC GTT GAM TCC AAT T-3')

${ }^{3}$ Archaeal DNA amplified using 109F (5'-ACK GCT CAG TAA CAC GT3') and 915R (5'-GTG CTC CCC CGC CAA TTC CT-3') 